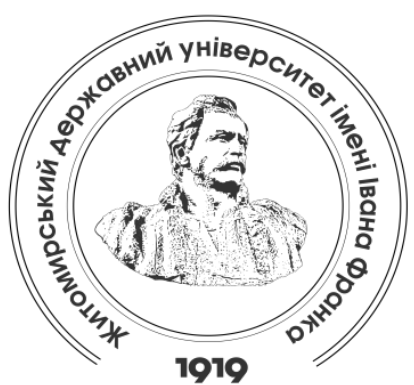

Zhytomyr Ivan Franko State University Journal. Philological Sciences. Vol. 2 (95)

Вісник Житомирського державного університету імені Івана Франка. Філологічні науки. Вип. 2 (95)

ISSN (Print): 2663-7642

ISSN (Online): 2707-4463

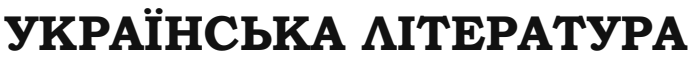

\section{УдК 821.161.2.09}

DOI 10.35433/philology.2 (95).2021.6-17

\section{НАРАТИВНІ ОСОБАИВОСТІ ОПОВІДАННЯ "ГЕЙ, ТИ, БОЧЕЧКО..." B. ВИННИЧЕНКА}

\section{А. В. Горбань*}

У статті на прикладі аналізу оповідання "Гей, ти, бочечко..." В. Винниченка простежено методологічні можливості наратології, які виходять за рамки традииійної поетики. Розглянуто визначення Ж. Женеттом основних категорій наратології: історії та дискурсу, анахроній, видів $i$ функиій наратора, наративної дистаниії та фокалізаиії. Насамперед запроваджені Ж. Женеттом категорії та парадигми розширюють можливості літературознавчого аналізу. Наприклад, у традииійній поетииі немає поняття на позначення суб'єкта бачення (фокалізатора). Розроблена Ж. Женеттом парадигма наративної перспективи дуже важлива для дослідження наративів, крім того, без иієї категорії оповідна техніка модернізму $\varepsilon$ взагалі незбагненною. Недостатньо уваги традииійна поетика приділяе анахроніям, розглядаючи їх разом з іншими "позасюжетними елементами", хоча аналепсис і пролепсис не є ані дискурсивними, ні описовими. Ж. Женетт подає детальну класифікаиію аналепсисів і пролепсисів, яка визначає функиіональність аналізу в контексті. З'ясовпно, шо женеттівський метод наратології не зводиться до визначення наративних категорій як елементів: ідеться також про їх стійке співвідношення, тобто наративну модель розповідних текстів.

В аналізованому оповіданні з'ясовано співвідношення telling, showing $i$ talking, вияви персонажного й атрибутивного дискурсу. Простежено в композииійному й семантичному аспектах художню доиільність задіяних письменником анахроній (аналепсисів і пролепсисів). Досліджено такі особливості оповідної манери В. Винниченка, як перевага мімезису над дієгезисом, а також характерні для модернізму наративну дистаниію й самоусунення автора завдяки фокалізаиії (внутрішнъої і зовнішнъої).

ключові слова: наратологія (за Ж. Женеттом), історія, дискурс, мімезис, дієгезис, наратор, фокалізаиія, аналепсис, пролепсис.

\footnotetext{
* кандидат філологічних наук, доиент кафедри українсъкої та зарубіжної літератур і методик їх навчання (Житомирський державний університет імені Івана Франка), anyasribnafog@gmail.com ORCID: 0000-0001-7092-4098
} 


\title{
NARRATIVE SPECIFICITY OF THE SHORT STORY "HEY YOU, LITTLE BARRELL..." BY V. VYNNYCHENKO
}

\author{
Horban A.V.
}

The paper discusses the methodological potential of narratology that extends beyond the boundaries of traditional poetics taking the text of Volodymyr Vynnychenko's short story "Hey you, little barrell..." as a case study. G. Genette's definitions of the basic categories of narratology, such as story, discourse, anachronies, narrator's types and functions, narrative distance and focalization are discussed. First and foremost, categories and paradigms introduced by G. Genette increase the possibilities of literary analysis. For example, there is no concept of a subject of vision (a focalizer) in traditional poetics. The paradigm of narrative perspective (focalization) developed by G. Genette is very important for studies of the narratives, besides, the narrative technique of modernism without this category is incomprehensible at all. Traditional poetics does not pay enough attention to anachrony, considering it together with other "off-plot elements", although analepsis and prolepsis are neither discursive nor descriptive. G. Genette presents detailed classification of analepsises and prolepsises, that determines the functionality of the analysis in context. Secondly, the paper clarifies, that the method of G. Genette's narratology is not limited to tracing narrative categories as elements - it is also about their constant interrelation, i.e. the narrative model of the stories.

Vynnychenko's short story is analyzed in terms of correlations between telling, showing and talking, as well as displays of character's discourse and attributive discourse. The artistic viability of anachronies (analepses and prolepses) is examined in the compositional and semantic aspects. The paper focuses on some specific features of Vynnychenko's narrative style, such as dominance of mimesis over diegesis, as well as narrative distance and the author's self-elimination by means of focalization (both the internal and external one) that are typical for modernist writing.

Keywords: G. Genette's narratology, story, discourse, mimesis, diegesis, narrator, focalization, analepsis, prolepsis.

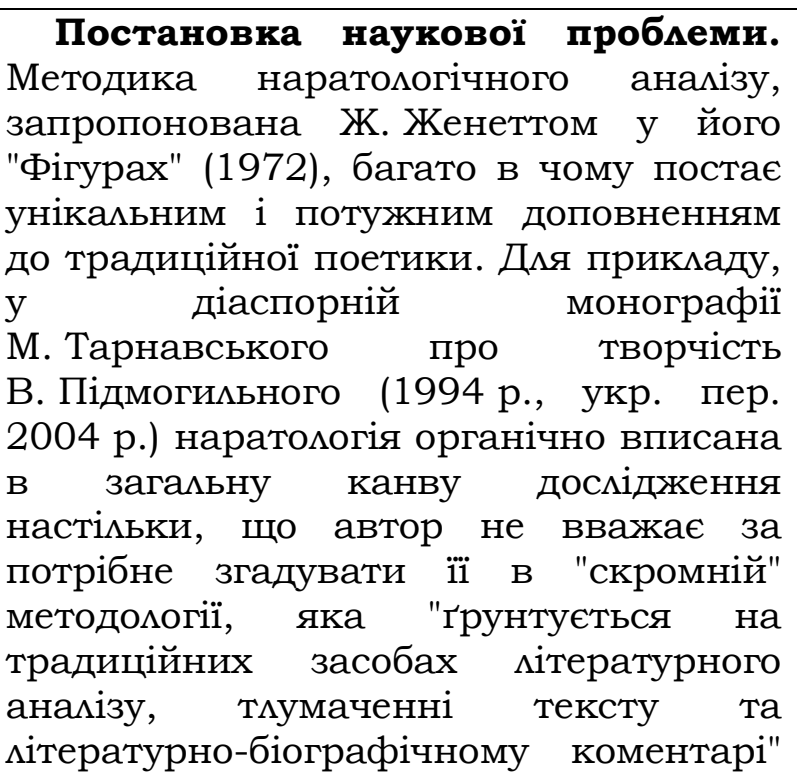
[6: 13], тобто дмя М. Тарнавського женеттівська категорія фокалізації уже цілком традиційний інструмент.

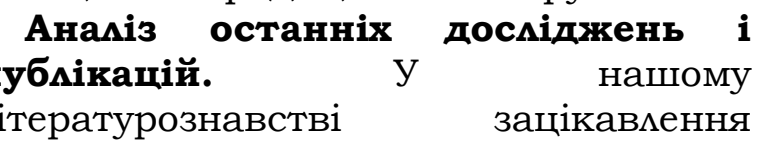
наратологією зростає, але навряд чи скоро вона стане традиційною; наразі iii застосовують спорадично й вибірково (до прози В. Винниченка О. Брайко, $\Lambda$. Мацевко-Бекерська, О. Чумаченко та ін.); і важко назвати дослідження, у якому теорія оповіді Ж. Женетта була б задіяна системно.

Одним із перших (1929 р.) наративні особливості прози В. Винниченка розглядав М. Зеров. Аналізуючи "Сонячну машину", дослідник простежує в ній "пережитки й гримаси старої манери" [3: 448] персоніфікований пейзаж, засвоєний "як норма" також Г. Косинкою (до речі, М. Тарнавський [6] окреслює відмову від такої метафоричності на користь об'єктивного опису в прозі іншого Винниченкового "учня" В. Підмогицьного). Але найбільше М. Зерова дратує не Винниченкова "стара манера", а популярний у 20х pp. ХX ст. "кінематографізм" (якщо мовою наратології, тут ідеться про перевагу мімезису над дієгезисом). Утім, варто зважити й на Винниченків досвід драматурга та на "природжену драматургічність його художнього 
мислення" [5: 26], які також позначилися на прозових творах. М. Зеров вважає "кінематографізм" затісним і навіть неадекватним для роману. Коментуючи епізод аварії мітака, дослідник пише: "Дия романіста ця сцена непотрібна; йому важне, вмастиво, не падіння, але прибуття доктора Штора до Берліна <...>. Драматургові ця сцена не потрібна також: падіння 3 аероплана не напружує становища, не веде дію до розв'язки. Потрібна ця сцена i достатньою мірою умотивована тільки 3 погляду кіносценариста, що, завваживши певну одноманітність картини, хоче розбити іiі якимось "трюковим номером", якимсь цікавим дмя ока моментом" [3: 443]. У зображенні персонажів "Сонячної машини", на думку М. Зерова, В. Винниченкові бракує психологізму, $і$ це знову "кінематографрізм" (наразі йдеться про зовнішню фокалізацію): "Рух і міміка панують у романі. <...> дійові особи складаються 3 фризури, рис обличчя та костюма" [3: 442]. Звернувши увагу на Винниченкову манеру оповіді, М. Зеров іiі переважно критикує. Але його студія цікава для нас 3 огляду на той же період творчості, що й обраний для розгляду текст - оповідання "Гей, ти, бочечко... " В. Винниченка з циклу "Намисто", написане у 20-х рр. XX ст.

мета пропонованої статті - на прикладі аналізу окремого оповідання простежити методологічні можливості наратології (за Ж. Женеттом), які виходять за рамки традиційної поетики, а також дослідити особливості й функції (відтак і художню доцільність) наративних категорій, притаманних для оповідної манери В. Винниченка.

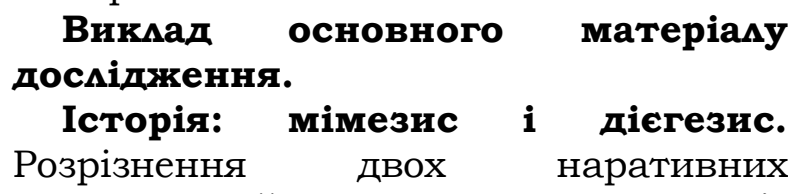
модальностей Ж. Женетт виводить із платонівського розмежування мімезису й "чистої розповіді", яка "повідомляє менше і більш опосередкованим способом" [2: 182]. Але дия Пматона йшлося про способи представлення мовцення, а не подій (у наратології "історії"). Ж. Женетт зауважує, що "ця опозиція, дещо нейтралізована Аристотелем (який перетворює чисту розповідь і пряме зображення у два різновиди мімезису) та ... ігнорована класичною традицією, взагалі не надто зайнятою проблемами наративного дискурсу, знову несподівано з'явицася в теорії роману в США й Англії, у кінці XIX й на початку XX століття, у працях Генрі Джеймса та його учнів, у вигляді майже дослівно перекладених термінів showing (показ) i telling (розповідь), які незабаром стали в нормативній англосаксонській традиції Ормуздом та Аріманом естетики роману" [2: 182183]. У теорії Ж. Женетта це, відповідно, мімезис (показінсценування подій, ілюзія безпосереднього й деталізованого сприймання, ніби на екрані) i на протилежному полюсі - дієгезис, платонівська "чиста розповідь", визначальними ознаками якої французький наратолог називає конденсацію та непрямий характер (посередником $\epsilon$ наратор). За Ж. Женеттом, "мімезис визначають максимум інформації і мінімум присутності інформатора, а дієгезис обернене співвідношення" [2: 185]. Дослідник робить висновок, що мімезис i дієгезис залежать від наративної інстанції (точніше, від міри ii присутності), а також від наративного темпу (який може впливати на ступінь деталізації).

На противагу мімезису, дієгезис дає змогу "стискати час", і тут - замість відчуттів, що наповнюють уяву пластичними деталями, - на перший план виходять мотивація та причиннонаслідкові зв'язки, наприклад: "З того часу, як пан прийняв до череди отого паршивого "скургуца", не бумо Семенові проходу від глузування всієї економії" [1: 43]. В оповіданні В. Винниченка "Гей, ти, бочечко... 
виразно переважає мімезис, але варто відзначити, що його наративний темп неоднорідний: час історії то пришвидшується, то сповільнюється, аж до описової статичності. Що характерно дця В. Винниченка - це мальовниче тривання (якщо не сказати "підвисання") мімезису, акцентоване надзвичайно пластичними деталями (як правимо, "працюють" не мише зір і слух, а й дотик і смак; нюх трапляється рідше): "Біля середньої копанки череда скупчується i довго п'є 3 неї та 3 калюжі. Семен Гедзь нетерпляче чекає, потім сам припадає до води і смокче іiі витягненими губами. У куточку копанки розпласталось чорненьке жабеня 3 жовтогарячим черевцем i застигло. / В зуби зайшов холод, коліна промокАи, в роті смак глини й болота. / Семен Гедзь утирається рукавом сорочки, оглядає череду і швиденько вибирається з осоки на горб" [1: 54]. Використовує автор і характерну для модернізму синестезію, наприклад, ховрашки "тоненько-тоненько пускають просто в Семена Гедзя свистом, наче гострим блискучим дротиком" [1: 52] (звук передано через дотик i зір). Пластичні деталі, які наповнюють історію відчуттям присутності, і віцьні мотиви, не важливі для розгортання сюжету, зумовлюють ретардацію, адже чекає не тільки Семен - мусить дочекатися розвитку інтриги й читач.

\section{Дискурс персонажний \\ наратора дискурс. \\ Ta} термінологічній традиції наратології історія - це telling (дієгезис) або showing (мімезис), а дискурс - це talking, не власне події, a ix обговорення, коментарі, судження, які в часі нарації належать оповідачу й навіть можуть формувати обрамлення для історії. У розмехкуванні об'єктивної історії та суб'єктивного дискурсу Ж. Женетт іде переважно за Е. Бенвеністом. Крім дискурсу наратора, важливим $€$ дискурс персонажний (у часі історіi): зовнішній (сказане чи написане) та внутрішній (думки героя). Якщо в "розповіді про події" $\epsilon$ мімезис i дієгезис, то в "розповіді про слова" поміж цими ж двома полюсами Ж. Женетт розташовує види персонажного дискурсу: максимально міметичним $\epsilon$ дискурс цитований, максимально дієгетичним - дискурс наратизований, a посередині $\epsilon$ ще дискурс транспонований, який почасти зберігає мовлення нередукованим, 3 індивідуальними особливостями, одначе "присутність оповідача надто явно відчутна в самому синтаксисі фрази, аби дозволити дискурсу стати документально-автономним, як цитата" [2: 190]. Так само, як у способах представлення історії, у розмежуванні видів персонажного дискурсу йдеться про міру "посередництва" наратора: якщо цитований дискурс передається безпосередньо, тобто ніхто не стає між мовомисленням героя та читачем, то дискурс транспонований змінює сказане / подумане принаймні граматично (одначе суб'єктивність героя залишається окремими фрагментами), а персонажний дискурс наратизований $\epsilon$ вже цікком "переказаним", відтак наративна перспектива персонажа в ньому зникає. На практиці, не маючи змоги зіставити представцений у творі персонажний дискурс із тим, як він "звучав" у "реальності" художнього світу, ромежувати транспонований i наратизований види дискурсу допомагає не тільки наявність / відсутність емоційних чи стилістичних маркерів мовлення персонажа, але також відчуття часткового / повного "стискання" часу, що в наратизованому дискурсі повністю редукує сказане до переказаного - суто інформаціі.

"Слова автора", які вводять персонажний дискурс, у наратології називають дискурсом атрибутивним, що, власне, і $є$ "розповіддю про слова". Так само, як і "розповідь про події", атрибутивний дискурс належить 
наратору, який може давати уяві читача неоднаковий "простір": від маконічної вказівки, кому належить мовцення, до детального уточнення комунікативного контексту персонажного дискурсу в плані перцептивному (інтонація, міміка, жести) чи й концептуальному (інтенції, переживання, оцінки почутого й сказаного).

У "Гей, ти, бочечко..." В. Винниченка оповідь належить власне автору, але дискурс наратора на початку пробивається єдиним зауваженням: "...був собі Семен Гедзь бравим парубчаком, трошки, скажемо, ще молоденьким (чотирнадцятий минав)..." [1: 43], а далі він практично відсутній, що є прикметою наративної техніки модернізму. Самоусунення "всюдисущого і всезнаючого" автора в модернізмі відбувається або на користь героя, або на користь читача (завдяки внутрішній чи зовнішній фокалізації про це далі). Отже, автор скупий на власні коментарі й судження, натомість історія не тільки чергується 3 персонажним дискурсом, а й ніби "забарвлюється" баченням героя: "Та ще не кінчає складати стеблини, як скургуц, озирнувшись, і собі біжить до пшениці. I воно висмикує стебла, i воно підбирає їх! От проклята душа!" [1: 49]. Останнє речення з цього тексту - персонажний дискурс (внутрішній, цитований), але обурення Семена Гедзя тим, що Семен Комар в усьому його наслідує, зокрема і в плетінні брилів, емоційно маркує (фокалізує) також історію (попередні речення): попри те, що розповідь ведеться від III особи, "скургуц", "воно" - це зневажииве ставлення не наратора, а персонажа.

Наратизований персонажний дискурс в аналізованому оповіданні трапляється зрідка та відповідає дієгезису: "Бабуся прощається, бурмотить якісь молитви... " [1: 58]. Наратизований дискурс не дає "почути" сказаного, передається мише загальна інформація ("Пан дозволяє пасти біля Трьох Копанок" [1: 47]), але коли він переходить у транспонований дискурс, мовлення персонажа (наразі пана) поєднується не тільки із "синтаксичною" присутністю наратора, а й із баченням фокалізатора (наразі адресата сказаного), відтак межа між дискурсами пана й Гедзя, тобто сказаним та осмисленим, майже зникає: "Паси, будь маска. Та тільки гляди: зайде хоч одна корова, хоч одне теля на баштан, - за півроку служби вищитується. Отож півроку служи дурно за те, що теля якогось соняшника надгризе" [1: 47-48].

Найбільш уживаним в оповіданні персонажним дискурсом є цитований, що відповідає мімезису. В. Винниченко ретельно деталізує індивідуальні особливості мовлення бабусі: "Ждоров, Шеменочку, ждоров, шиночку! А де ж мій мобуряка?" [1: 53] та обох Семенів: "Та ти цого ціпляєсся до мене, цортова дусе?! - А цого?" [1: 45]. Однак ці вади мовлення проступають тільки в перших репліках "знайомства" 3 героями. Якби автор "змушував" бабусю й надалі беззубо шепемявити, це спричинимо б комічний ефект, тож далі в тексті її мудрі настанови внукові подано цитованим дискурсом, але без жодних вад: "...I не сварися, синку, не сварися, дитино моя. Ви ж обидва сирітки собі, наймиточки собі бідненькі, працьовнички гіркі..." [1: 56]. I так само поза експозиційною частиною обидва Семени, розмовляючи та співаючи "Гей, ти, бочечко...", усі шиплячі вимовцяють.

Як i дискурс наратора, атрибутивний дискурс у В. Винниченка часто буває відсутній (якщо належність репліки й так зрозуміла $з$ контексту), і письменник ніколи не обмежується нейтральними вказівками на мовця, як-от "Семен сказав" чи "бабуся запитала". Якщо вже автор подає атрибутивний дискурс, то для уточнення інтонації, тону ("весело- ююто гукає" [1: 49], "бурмотить" [1: 49], "криком перебиває бабине буботіння" [1; 56], "прокашлявшись, Семен Гедзь 
розгойдує пісню знизу" [1: 60]), а також міміки й жестів як зовнішніх виявів внутрішнього стану мовця: "Тут Семен Гедзь здивовано витріщується на пана. - На якому баштані? (...) - Та он на тому, серденько! От там-о-о! Аюбенько показує пан пужалном гарапника до баштану" [1: 60-61]. До речі, здивування $\epsilon$ чи не найбільш поширеною емоцією в атрибутивному дискурсі оповідання (у наведеному прикладі воно вдаване), але не менш прикметним для наративної манери В. Винниченка $\epsilon$ показ замість називання: зокрема, за ввічиивим жестом (Аюбенько) проглядається погроза - гарапник, ця деталь означує неназване переживання страху. Отже, атрибутивний дискурс конкретизує комунікативний контекст сказаного.

Анахроніями $Ж$ Ж. Женетт називає "різні форми невідповідності між порядком історії та порядком нарації" [2: 73]. Позначивши хронологічну (фабульну) послідовність епізодів числами, а сюжетний порядок викладу - мітерами, можемо отримати схематичний запис композиції уривка (для цілого твору такий аналіз був би надто громіздким). Дослідник підкреслює, що анахронія - цікком традиційний засіб у мітературних наративах (на відміну від фольклорних), наявний уже навіть у Гомера.

Художня доцільність анахронії визначається в контексті первинної нарації, від якої анахронія "відбруньковується", тож ідеться не про власне елемент (вкраплення подій минулого чи майбутнього), а про його зв'язки в структурі наративу. Композиційні аспекти оповіді не вичерпуються анахроніями, але останні яскраво демонструють переваги наратології порівняно 3 традиційною поетикою, де під спільною назвою "позасюжетні елементи" зібрано різнотипні категорії: образні (як-от пейзаж), дискурсивні (наприклад, ліричний відступ) та подієві (зокрема, екскурси в минуле).
Натомість поетикальний аналіз не зважає ні на контекст тих антиципацій i ретроспекцій, тобто їхню художню доцікьність саме в певному місці первинної нарації, ні на те, що "позасюжетні" екскурси в майбутнє чи в минуле функціонально не відрізняються від тих, які в рамках сюжету, а бувають i змішані. У наратології Ж. Женетта анахронія - це вторинна (суто за порядком) оповідь, аналіз таких часових "невідповідностей" не тільки привертає увагу до їхньої ромі, а й повертає їх до контексту первинної оповіді, що, вочевидь, має більше могіки, ніж парадигма "позасюжетних емементів", адже анахронія представцяє не образ, не дискурс, а саме історію (story, розповідь про події).

Пролепсис у теорії Ж. Женетта - це анахронія, що забігає наперед, розповідаючи (прямо або символічно) про подію, що трапиться в майбутньому щодо часового проміжку, про який розповідає первинна нарація. Анахепсис - розповідь про подію 3 минулого, яка також визначається щодо часу, про який ідеться у первинній нарації.

Перш ніж братися до розгляду анахроній, варто відмежувати час історії (змісту оповіді, тобто подій) від часу нарації (процесу розповідання), особливо у творах, де наявне обрамлення: його час, упізнаваний за дискурсом наратора, бажано відразу винести "за дужки". Почасти практичний розгляд ускладнює саме плутанина, спричинена схожістю називання: насправді анахронію як "вторинну нарацію" (яка, зі свого боку, може бути "первинною нарацією" дмя іншої анахронії) не можна розглядати як власне нарацію: аналіз анахроній це про інверсовану послідовність подій, переставцений порядок частин історії (художнього світу, де "живуть" персонажі), безвідносно до часу, у якому ведеться оповідь (наратором дия нарататора). Класифікацію аналепсисів і пролепсисів Ж. Женетт 
подає спільну, вирізняючи їхні різновиди за кількома критеріями. Поперше, зовнішній / внутрішній / змішаний - щодо часового проміжку сюжету, відповідно або цілком поза хронологією сюжету, або в його подієвих рамках, або анахронія вмішує як сюжетний, так і позасюжетний час. По-друге, якщо аналепсис / пролепсис внутрішній, то буває гомо- / гетеродієгетичним (однакова чи інша сюжетна мінія, порівняно з первинною нарацією). По-третє, якщо аналепсис / промепсис гомодієгетичний, може бути додатковий / повторний (перший заповнює доти не з'ясовані "прогалини" в історії, а другий повертає читача до подій, які вже були представлені в розповіді, можливо, в іншому інформативному обсязі чи в інакшій мотивації / перспективі). По-четверте, повний аналепсис / пролепсис, перериваючи часовий проміжок первинної нарації, від якої "відбіг", до неї повертається, тобто історія продовжується 3 того ж місця (точніше, з того самого часу), натомість після часткової анахронії розповідь не повертається до первинної нарації, а переходить до іншого часу (аналепсису чи пролепсису), утворюючи складнішу композицію.

В оповіданні В. Винниченка "Гей, ти, бочечко..." розповідь - цілком традиційно - починається in medias res: "Семен Гедзь постановив за всяку ціну здихатись Семена Комара" [1: 43]. Це час первинної нарації, відповідно до якого далі в межах експозиції "перетасовано" кілька внутрішніх аналепсисів. Їхня фабульна послідовність така: 1) майбутній черідник Семен, іще не Комар, старцює, водить свою глуху бабцю - і в тому ж часі ще не знайомий із ним Гедзь почувається соціально успішним; 2) пан дає хлопцеві роботу; 3) у компанії молодшого Семена зі старшого Семена починають глузувати, зокрема й через те, що новий черідник в усьому наслідує Гедзя (за що й отримує прізвисько Комар).
У послідовності сюжету ці три часи чергуються. Аналепсиси "золотої" дмя Гедзя пори (1) $€$ додатковими, а от зміна ситуації (2) після першої згадки ще двічі варіюється повторними аналепсисами: "3 того часу, як пан прийняв до череди отого паршивого "скургуца" <...> А як чортяка прибила до двору отого шмаркача <...> I надала ж чортяка панові набачити стару на дорозі та зманити в неї іï скургуца!.." [1: 43-44]. Варто зауважити, що схема 2-1-3 також повторюється - 3 акцентуванням часів "до" (1) і "після" (3) спочатку дия Гедзя, потім дия Комара. А третій раз це тільки 2-3, але тут аналепсис (2) гетеродієгетичний - 3 акцентом на мотивах (i наслідках) дия бабці, яка віддала внука в найми, приставши на пропозицію пана. Як бачимо, В. Виниченко, попри фіксовану фокалізацію оповіді упередженим баченням Гедзя, дозволяє читачеві скласти власну думку, адже подає в експозиції не мише три часи, а й три ракурси історії.

Гедзь намагається реалізувати свій намір позбутися небажаного "комеги", ase так, щоб уникнути гніву пана ("уже й маяв, і штурхав, і навіть бив не раз скургуца" [1: 46]) - і це хронікальний виклад аж до слів, які обіцяють перипетію: "Ну, та Семен Гедзь уже знав, як іздихатись цього старця!" [1; 46]. Інтрига привабливо-загрозливих "Трьох Копанок", до яких хлопець "сьогодні чогось усе ж таки рішився" [1: 48] гнати череду, надалі підтримується трьома повторними пролепсисами, одначе автор не відразу розкриває весь задум: "Сьогодні - середа. А щосереди стара старчиха мазить одвідувати свого онука. От і відвідає. Семен Гедзь аж посміхається про себе <...> Семен Гедзь посміхається: співай, співай, поспіваєш ти іншої сьогодні, скургуце чортів! <...> Семен Гедзь із усміхом зирка... Ач, причепилася московська пеня, влипла в чоловіка, як трясця. Ну, та як приліпив пан, то сам же й одиіпить!" [1: 49-51]. Повторювані "штрихи" зцовтішного настрою (знову модерністична техніка) 
залишають читача все ще "голодним" в інформативному плані. I мише 3 початком реалізації задуму, коли він і так стає розумілим, бо ж Гедзь, узявши на себе череду Комара, поки той спілкується з бабцею, підганяє телят до баштану, 3 цією останньою частиною "пазцу" підступний пцан нарешті з'ясовується - ще одним пролепсисом: "Двері куреня дивцяться на гору, так що скургуц не зможе побачити, як знизу телята позалазять на баштан. (...) Пан налетить, застукає телят та цошат на баштані, і нехай собі тоді ціиується 3 скургуцом та його бабусею" [1: 55]. Використання пролепсисів, як бачимо, тут цілком підпорядковане утримуванню перипетійної інтриги. Тим більш несподіваною дия читача стане зміна не ситуації, а ставцення - оте аристотелівське "впізнавання", через яке ці ретельно сплановані візії майбутнього так і не будуть реалізовані. Цікаво, що в другій частині оповідання, після зміни ставлення Гедзя до Комара, анахроній більше немає. Розглянувши аналепсиси й пролепсиси, помічаємо постійну неповноту інформації: автор почасти розкриває мотиви й задуми персонажа, проте своїм всезнанням не ділиться.

\section{Види й функціi наратора.} Критеріями типологіі нараторів, за Ж. Женеттом, $\epsilon, \quad$ по-перше, перебування поза художнім світом / усередині художнього світу (екстрадієгетичний / інтрадієгетичний наратор) та, по-друге, стосунок до історії, про яку наратор розповідає знову ж таки або "зсередини", або "ззовні" подій (гомодієгетичний / гетеродієгетичний наратор). При цьому Ж. Женетт скептично ставиться до традиційних означень викладу від першої та від третьої особи: "Вибір романіста робиться не 3 двох граматичних форм, а 3 двох наративних позицій (граматичні форми $\epsilon$ мише їх механічними наслідками): або оповідь буде вести один із "персонажів", або оповідач, сторонній стосовно цієї історії. Наявність дієслів першої особи в наративному тексті може, таким чином, відсилати до двох цілком відмінних ситуацій, які граматика змішує, але наративний аналіз має розмежовувати" [2: 253-254]. Відрізнивши гомодієгетичного наратора-персонажа від гетеродієгетичного наратора-свідка (котрий не бере жодної участі в подіях, про які розповідає), дослідник також уточнює: "Відсутність має абсолютний характер, а присутність має різні ступені. Тому всередині гомодієгетичного типу треба розмежовувати принаймні два підтипи: один - коли наратор є героєм власної оповіді..., інший - коли він грає мише другорядну роль, яка виявляється практично завжди ромлю спостерігача й очевидця" [2: 254].

В оповіданні В. Винниченка "Гей, ти, бочечко... " наратор екстрадієгетичний гетеродієгетичний, однак наскрізна оповідь від третьої особи в першій частині (до "впізнавання") виразно фокалізована.

Функції наратора Ж. Женетт визначає відповідно до різних аспектів розповіді. Стосовно історії наратор виконує функцію наративну (єдину обов'язкову й постійну); щодо тексту, "про який оповідач може говорити в рамках особливого метамовного (у нашому випадку - метанаративного) дискурсу, окреслюючи його поділ, зв'язки, внутрішні відношення, словом - його внутрішню організацію" [2: 263264], він виконує режисерську функцію; стосовно наративної ситуації, тобто діалогу наратора 3 нарататором (такий адресат може бути наявним, відсутнім або потенційним), оповідач виконує комунікативну функцію; а щодо самого себе, точніше - своєї належності (участі) і свого ставлення до історії (емоційного, морального тощо), наратор може виконувати функцію свідчення, якщо він, до прикладу, "вказує джерело своїх відомостей чи оцінює ступінь точності своїх спогадів" [2: 264], та функцію ідеомогічну, за якої втручання 
наратора

"набувають

більш дидактичної форми авторитетного коментаря" [2: 265]. Варто зауважити, що ідеологічна функція яскраво виявцяється тоді, коли історія слугує мише доведенням-ілюстрацією певної ідеї, а функцію свідчення, як правимо, найкраще виконує "поселений" у художній світ інтрадієгетичний, але гетеродієгетичний наратор.

В оповіданні В. Винниченка "Гей, ти, бочечко..." автор самоусувається на користь персонажа й читача, відтак функція наратора обмежена до єдиної обов'язкової - наративної. Безперечно, автор має свою концепцію, але прямо іï не декларує, він уміло компонує текст, ase не ділиться 3 читачем режкисерськими вказівками, загалом присутність наратора майже непомітна. Замість наратора інші його функції виконує персонаж фокалізатор): це Семен Гедзь у невласне прямій мові комунікує 3 уявним співрозмовником, він же режисує свій "проєкт" майбутнього розгортання подій, це його досвідом і ставленням забарвлено оповідь у першій частині твору: "Вже отак Семен Гедзь одслужив йому дурно півроку" [1: 48] - функція свідчення, "I хоч би ж тобі, закляте, хмикнуло, хоч би слово бовкнуло, що Семен Гедзь собі межить, а воно ганяє" [1: 45] - ідеологічна функція (правда, завдяки наративній дистанції спрацьовує як "доведення від супротивного").

Наративна

фокамізація створюють суб'єктивну модальність оповіді. Наративна дистанція - це часова, культурна, світоглядна, моральна, емоційна чи інша "відстань" між нарацією та історією, переважно між наратором i протагоністом, aле іноді таку дистанцію створює й фокалізатор. Зокрема, "обмеження поля" внутрішньої фокалізації Ж. Женетт вважає особливо ефектним у наративі "Що знала Мейзі" Г. Джеймса, де "ми практично ніколи не полишаємо точки зору маменької дівчинки" [2: 206], яка не розуміє сенсу "дорослих" подій.
Фокалізація, або наративна перспектива, - категорія наратології, що представляє залежність розповіді від наявних / відсутніх перцептивних / концептуальних обмежень.

Характерною для багатьох творів В. Винниченка $є$ "подача подій у зворотньому насвітленні - від першої особи, яка $€$ персонажем виразнонегативним, і тому представляє речі крізь призму свого викривленого світосприймання" [4: 151]. В оповіданні "Гей, ти, бочечко..." за таким принципом "зворотнього насвітмення" змодельовано наратив першої частини, пересиченої персонажним дискурсом й фокалізованої "викривленим" баченням Гедзя, наприклад: "Ну, стара, дурна, розжалілась та й віддала свого поводатаря..." [1: 44] (із жодного іншого погляду, вкАючно з читацьким, цей вибір на користь онука не $\epsilon$ "дурним"). Отже, наявна моральна й емоційна наративна дистанція. Але в другій частині твору (від епізоду підскуховування) ця дистанція знімається, а з нею несподівано зникає й мелодраматичність переслідувння пасивної жертви (Комара) підступним миходієм (Гедзем): тепер старший не тільки намагається виправити ситуацію, а й бере на себе відповідальність: шляхетно бреше, ніби біля баштану була його череда. Ще раніше зникає часова дистанція, тож читач ніби "впритул" наближений до безпосереднього проживання історії персонажами.

Розмову про типи фокалізації Ж. Женетт починає 3 аналізу різних класифікацій наративних ситуацій, критикуючи їх за скомплікованість, адже суб'єкт мовлення й суб'єкт бачення переважно не розмежовуються. Зокрема, Б. Ромберг "звернувся до типології Штанцеля, яку він доповнив четвертим типом: об'єктивна розповідь у біхевіористському дусі (це сьомий тип, за Фрідманом), звідки виходить такий чотиричменний подік: 1) розповідь від 
всезнаючого наратора, 2) розповідь із певної позиції, 3) об’єктивна розповідь, 4) розповідь від першої особи. <..> Борхес, напевно, ввів би тут п'ятий, чисто китайський клас - розповідь, накреслена тонким помазком" [2: 205], - іронізує Ж. Женетт, адже парадигми немає: критерій визначення четвертого типу (розповідь від першої особи) не збігається з іншими в цій класифікації: перші три типи залежать від бачення, а не від наративної інстанції.

Відштовхуючись від попередників, Ж. Женетт пропонує вцасну типологію фокалізації. Перший тип, який наявний насамперед у класичних наративах, - це в теорії Ж. Женетта "нефокалізована розповідь, або розповідь із нульовою фокалізацією" [2: 206], де немає ні концептуальних, ні перцептивних обмежень. Другий тип дослідник називає "розповіддю 3 внутрішньою фокалізацією" [2: 206], яка має концептуальні обмеження. Внутрішня фокалізація може бути або фіксованою (протягом цілого твору події представлено в баченні одного персонажа), або змінною (історія подається в баченні то одного, то іншого персонажа, фокалізатори чергуються), або множинною (одна й та сама подія фігурує в оповіді неодноразово - у перспективі різних фокалізаторів). Третій тип фокалізації, співвідносний 3 "об'єктивною розповіддю", як-от у "Білих слонах" Е. Гемінгвея, - це в теорії Ж. Женетта зовнішня фокалізація, за якої "читач не допускається до будь-якого знання думок і почуттів головного героя" [2: 206], тобто обмеження наявні, але суто перцептивні.

Нульова фокалізація передбачає всюдисущого й всезнаючого наратора. Одначе (кожен оселедець - риба, але не кожна риба - осемедець) екстрадієгетичний наратор (власне автор) може використовувати як нульову, так і зовнішню чи внутрішню фокалізації, бо він не завжди демонструє читачеві своє всезнання чи принаймні свою концептуальну позицію. Як уже зазначено, у наративній моделі модернізму використання в третьоособовому викладі внутрішньої / зовнішньої фокалізації суттєво звужує "монополію" автора або на користь фокалізатора, який "забарвцює" історію своїм суб'єктивним баченням (адже дия модернізму важливий саме ракурс), або на користь читача, який мусить самостійно робити висновки, інтерпретуючи суто зовнішні вияви жести, міміку, дії. В останньому випадку модерністичний наратив, по-перше, посилює інтригу (за відсутності повноти інформації, якою автор володіє, але наратор нею не ділиться), по-друге, позбавлений не тільки підказок автора, а й одкровень персонажа, читач мусить відчути релятивність добра і зма, маючи також вільний простір для вцасних припущень.

Гомодієгетичний наратив, за якого наратором $\epsilon$ протагоніст, також не означає, що це буде саме внутрішньо фокалізована оповідь, тобто що буде передане бачення саме цієї особи, i саме як учасника подій (у часі історії, а не в часі нараціі). Ж. Женетт пише: "... із використання "першої особи", іншими словами, із особової тотожності наратора й героя, жодною мірою не випливає фокалізація оповіді на героєві" [2: 213].

Нарешті, інтрадієгетичний гетеродієгетичний наратор, який "мешкає" в художньому світі, на перший погляд, не може поєднуватися ні 3 нульовою фокалізацією (як

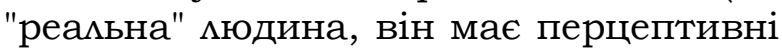
обмеження), ні 3 внутрішньою фокалізацією на персонажеві (як "реальна" ^юдина, такий наратор не може "влізти в голову" іншому), але це суто в теорії, а на практиці письменники використовують різні види фокалізації "в обхід" ними ж створеного гетеродієгетичного наратора як усього мише вигідної "маски" автора. До речі, порушення коду фокалізації, коли читач отримує інформації менше або більше, аніж 
передбачає заданий для контексту код, Ж. Женетт називає апьтераціями.

Внутрішню фокалізацію мегко сплутати 3 дискурсом наратора. Але дискурс (talking) завжди суб'єктивний, він не може бути фокалізованим або ні. Фокалізованою буває тільки історія (telling / showing), де діють або концептуальні обмеження (внутрішня фокалізація, справді, створюється вкрапленнями персонажного дискурсу до історіі), або обмеження суто перцептивні - читач може бачити, чути, загалом сприймати художній світ разом із персонажами, проте тільки тут-і-тепер, у межах фізичної "досяжності" відчуттів зору, слуху тощо (зовнішня фокалізація). Фокалізація нумьова, якщо, по-перше, немає персонажа-фокалізатора (при цьому оповідач може оперувати внутрішніми мотивами поведінки героїв, "читати" їхні думки, однак бачення персонажів не забарвлює розповідь, не "звужує" іiі концептуально) i, по-друге, за відсутності перцептивних обмежень немає жодних "зачинених дверей" часопростору, куди б наратор не міг "провести" свого читача.

В оповіданні В. Винниченка "Гей, ти, бочечко..." в першій частині домінує внутрішня фіксована фокалізація, фокалізатором $є$ Семен Гедзь, і навіть на суто зовнішнє сприймання незмінно проєктується його настрій: "Повітря мерехтить хвильками, хилитається, і часом, як приплющиш очі, здається, що корови трусяться від заціпленого сміху" [1: 52]. A^е використовується й зовнішня фокалізація, що акцентує на перцептивних обмеженнях: "Семен Комар щось криком розповідає старій, аж ніби стрибаючи їй у мице. Та вітрець заносить слова у степ, і нічого не можна розібрати..." [1: 54]. Переломним моментом $\epsilon$ епізод підслуховування (аристотелівське "впізнавання"), у якому "Семен Гедзь прикушує нижню губу, а вона все чогось труситься" [1: 57]. Читач має здогадатися, що герой зворушений почутим, одначе його емоції конкретно не названі. Тут попереднє чергування внутрішньої та зовнішньої фокалізації змінюється виразним домінуванням останньої. I в цьому $\epsilon$ художня доцікьність: якби автор так і залишив читача "в голові" Семена Гедзя, було би значно важче зробити неочікуваним його подальший вибір - збрехати панові, захищаючи Комара (a несподіванка, здивування для В. Винниченка - понад усе).

Нульової фокалізації письменник (і в цьому оповіданні, і загалом) уникає, даючи змогу читачеві не тільки бути поряд із персонажами, "тут і тепер", а й робити власні висновки. Наприклад, хлопці "бачать, як пан підүіжджає до баштану, як змазить із коня i, нахилившись до землі, щось розглядає. Потім помалу іде понад межею i придивцяється, шукає слідів! Нарешті сідає на коня і їде собі вгору" [1: 61] (простежується зовнішня фокалізація). Але це саме хлопці роблять 3 побаченого висновок: "Нічого, значить, не помітив!" [1: 61], а читач може зважити й на те, що пан був вражений шияхетною брехнею Гедзя, чи не тому й вирішив "не помічати" заподіяної телятами й мошатами (чередою Комара) шкоди.

\section{Висновки й перспективи дослідження. $\mathrm{y}$ системному} застосуванні наратологія постає продуктивним методом, який вигідно доповнює поетикальний аналіз. Чи не найбільш новаторськими здобутками наратології Ж. Женетта, що незамінні в практичному застосуванні, адже (за браком відповідних категорій) були переважно обдікені увагою в традиційній поетиці, є насамперед дві парадигми: по-перше, детальна класифікація анахроній, яка дає змогу не просто включити оповідні аспекти до аналізу композиції, а й зробити цей аналіз структурним, по-друге, парадигма фокалізації, що дає змогу "помітити" поряд із суб'єктом мовлення (автор / оповідач) і суб'єктом дії (персонаж) ше одного суб'єкта - 
фокалізатора, якому належить бачення. Характерними особливостями оповідної манери В. Винниченка, що проявилися і в оповіданні "Гей, ти, бочечко...", $є$ перевага мімезису й цитованого дискурсу, уживання повторних аналепсисів і пролепсисів, застосування фокалізації та наративної дистанції для "зворотнього насвітлення". Модерністичне "самоусунення" автора позначилося, по-перше, відмовою від нульової фокалізації, натомість використанням внутрішньої (домінує в першій частині твору) і зовнішньої (переважає в другій частині), по-друге, практично відсутнім дискурсом наратора й обмеженістю його фрункцій (Аише наративна) - на користь персонажного дискурсу й навіть виконання фокалізатором функції свідчення, ідеологічної, комунікативної та режисерської функцій. У перспективі системне застосування методу наратології як до прози В. Винниченка, так i до інших наративів, а відтак дослідження наративних моделей української мітератури.

\section{СПИСОК ВИКОРИСТАНИХ ДЖЕРЕА TA МITEPATУРИ}

1. Винниченко В. К. Намисто. К.: Веселка, 1989. 380 с.

2. Женетт Ж. Фигуры. В 2 т. Т. 2. М.: Изд-во им. Сабашниковых, 1998. $472 \mathrm{c}$.

3. Зеров М. Українське письменство ХХ ст. Від Куліша до Винниченка: мекції, нариси, статті. Дрогобич: Видавнича фірма "Відродження", 2007. 568 с.

4. Качуровський I. Про деякі технічні засоби Винниченкової прози. Сучасність. 1997. № 1. С. 148-152.

5. Михида С. Слідами його еспериментів: Змістові домінанти та поетика конфмікту в драматургії
Володимира Винниченка. Кіровоград: Центрально-Українське видавництво, 2002. 192 c.

6. Тарнавський М. Між розумом та ірраціональністю: проза Валер'яна Підмогицьного / пер. 3 англ. В. Г. Триліс. К.: Університетське видавництво "Пульсари", 2004. 232 с.

\section{REFERENCES (TRANSLATED \& TRANSLITERATED)}

1. Vynnychenko V. K. (1989). Namysto [The Necklace]. Kyiv: Veselka. 380 p. [in Ukrainian].

2. Zhenett Zh. (1998). Figury [Figures] (Vol. 2). Moscow: Izd-vo im. Sabashnikovykh. 472 p. [in Russian].

3. Zerov M. (2007). Ukrainske pysmenstvo 20 st. Vid Kulisha do Vynnychenka: lektsii, narysy, statti [Ukrainian Literature of the 20th Century. From Kulish till Vynnychenko: lectures, essays, articles]. Drohobych: Vydavnycha firma "Vidrodzhennia". 568 p. [in Ukrainian].

4. Kachurovskyi I. (1997). Pro deiaki tekhnichni zasoby Vynnychenkovoi prozy [About Some Technical Means of Vynnychenko's Prose]. Suchasnist. 1, 148-152. [in Ukrainian].

5. Mykhyda S. (2002). Slidamy yoho esperymentiv: Zmistovi dominanty ta poetyka konfliktu $v$ dramaturhii Volodymyra Vynnychenka [Ttracing His Experiments: Semantic Dominants and The Poetics of Conflict in Volodymyr Vynnychenko's Plays]. Kirovohrad: Tsentralno-Ukrainske vydavnytstvo. 192 p. [in Ukrainian].

6. Tarnavskyi M. (2004). Mizh rozumom ta irratsionalnistiu: proza Valeriana Pidmohylnoho [Between Reason and Irrationality: The Prose of Valerian Pidmohyl'ny]. Kyiv: Universytetske vydavnytstvo "Pulsary". 232 p. [in Ukrainian]. 